\title{
Modeling seasonal branch carbon dynamics in pistachio as a function of crop load
}

\author{
Giulia Marino $^{\text {a, * }}$, Paula Guzmán-Delgado ${ }^{a}$, Tiziano Caruso ${ }^{b}$, Francesco Paolo Marra $^{\mathrm{c}}$ \\ ${ }^{a}$ Department of Plant Sciences, University of California, Davis, CA 95616, United States \\ ${ }^{\mathrm{b}}$ Department of Agricultural, Food and Forest Sciences (SAAF), University of Palermo, 90128 Palermo, Italy \\ ${ }^{\mathrm{c}}$ Department of Architecture (DARCH), University of Palermo, 90128 Palermo, Italy
}

\section{A R T I C L E I N F O}

\section{Keywords:}

Pistacia vera L.

Alternate bearing

Carbohydrates

Sink-source

Photosynthesis

Carbon partitioning

\begin{abstract}
A B S T R A C T
A simplified model for the prediction of carbon balance was developed to elucidate the seasonal trend of sinksource relationships in bearing and non-bearing pistachio (Pistacia vera L.) branches. Seasonal changes in growth rate of vegetative (leaf and shoot) and reproductive (infructescence) organs were monitored in branches of mature rainfed pistachio trees during the entire growing season (April-September). Simulations from the model were used to gain understanding of the implications of crop load on branch carbon (C) depletion and alternate bearing.

Results showed that the pistachio branch was energetically able to sustain up to two infructescences $(\sim 28$ fruits) having a slightly positive carbon budget $(2.6 \mathrm{~g}$ of $\mathrm{C})$ at the end of the season. A branch with 4 infructescences ( $\sim 56$ fruits) ended the season with a very negative carbon budget $(-14.1 \mathrm{~g}$ of $\mathrm{C})$ suggesting the implication of resource mobilization during heavy crop load.

The simulations with the model allowed the identification of two energetically critical periods for pistachio, both characterized by a decreasing trend of the carbon budget. The first is at the beginning of the season, from leaf out until 35/40 days after full bloom (DAFB), when leaves are still not source of carbon, and the branch energetic need is largely satisfied by the remobilization of carbon from the reserves accumulated the previous year and stored through the winter. The second critical period is at the end of the season for bearing branches, at 100 DAFB, when a strong reduction in leaf area due to early leaf senescence and drop coincides with high carbon request for kernel growth. Overall, results demonstrate that the branch carbon budget model is a valid tool to study bearing dynamics in tree species and can help to develop physiologically-based management strategies for achieving increased and more constant productions in pistachio orchard systems.
\end{abstract}

\section{Introduction}

Alternate bearing is typical of many plant species and can be defined as a periodic variation of the degree of fructification which can be synchronized over large areas. This phenomenon has been long studied in different crop species such as almond (Milella and Agabbio, 1978), apple (Beattie and Folley, 1978; Monselise and Goldschmidt, 1982; Williams, 1989), avocado (Chandler, 1950; Monselise and Goldschmidt, 1982), Citrus spp. (Goldschmidt and Monselise, 1977; Monselise et al., 1981), mango (Chacko, 1986), olive (Monselise and Goldschmidt, 1982; Stutte and Martin, 1986), pecan (Wetzstein and Sparks, 1986) and pistachio (Crane and Nelson, 1971; Monselise and Goldschmidt, 1982) with the main aim of minimizing the alternation of the cropping cycle.
Similarly, alternate bearing (or masting if synchronized over large areas) has been widely studied in ecology to decipher the potential competitive advantage of this behavior in natural ecosystems (Bogdziewicz et al., 2017; Perea et al., 2013; Shibata et al., 2020).

Depending on the species, different productive patterns can trigger the yield reduction generally observed the year after a very high cropping season:

1) reduced induction and differentiation of reproductive buds (Chan and Chan, 1967; Couranjon, 1989; Monselise and Goldschmidt, 1982; Post and Stam, 1983; Stutte and Martin, 1986);

\footnotetext{
* Corresponding author.

E-mail address: giumarino@ucdavis.edu (G. Marino).
} 
2) reduced vegetative growth affecting reproductive bud production potential (Addicott and Lyons, 1969; Couranjon, 1989; Crane and Al-Shalan, 1977);

3) abscission of reproductive buds during fruit growth (Crane, 1984; Crane and Iwakiri, 1987; Crane and Nelson, 1971; Monselise and Goldschmidt, 1982; Porlingis, 1974).

The latter has been described only in species belonging to the genus Pistacia and its physiological explanation is still under debate. The hypothesis that some growth regulators are involved in the process of bud abscission (Agrawal et al., 1980; Chacko et al., 1972; Crane and Iwakiri, 1987) was not confirmed by some experimental trials (Crane and Nelson, 1972; Takeda et al., 1980; Vemmos et al. 1994). Similarly, the hypothesis that alternate bearing in pistachio is related to resource competition between reproductive buds and growing embryos, strongly supported by several studies (Crane and Nelson, 1971, 1972; Crane et al., 1973; Crane, 1984; Caruso et al., 1995; Spann et al., 2008; Rosecrance et al., 1998), fails to explain entirely the bud abscission phenomenon. The higher carbohydrate accumulation observed in non-bearing branches (without fruits) versus bearing branches (with fruits) (Nzima et al., 1997a, Marra et al. 1997) is not supported by the tree level estimations reported by Stevenson and Shackel (1997). These authors found that, considering the whole tree, the total amount of carbon used through the entire season in "off" trees is the same as in "on" trees and suggested a switch of allocation priority from vegetative to reproductive growth and vice versa similar to the masting phenomenon described in several forestry species, as a possible explanation of alternate bearing in pistachio.

Resource partitioning among plant organs is a complex phenomenon that depends on the amount of available resources and the capability of the organs to use or store these resources (Monselise and Goldschmidt, 1982). All organs that are net producers of photoassimilates in a specific time are defined as "source" while organs that are net importers of photoassimilates in a specific time are defined as "sink" (Génard et al., 2008; Lacointe 2000; Grossman and DeJong, 1994).

The relation between sinks and sources plays a central role in the use and distribution of carbohydrates in trees. Each organ has a specific source or sink strength, defined as the capability to fix or use metabolites (Faust, 1989; Grossman and DeJong 1994). This strength depends on: 1) the ontogenetic phase of the organ, 2) the organ relative size, 3) the distance from the source, and 4) the availability of resources (Ho, 1988; DeJong 1999). In pistachio, the growing fruits are considered strong sinks and, during high cropping years, their development can depress vegetative growth (Weinbaum et al., 1994; Brown et al., 1995; Rosecrance et al., 1996; Picchioni et al., 1997). However, contrasting results are reported in literature showing enhanced vegetative growth during the bearing years (Crane and Nelson, 1972; Crane and Al-Shalan, 1977; Nzima et al., 1997b), or similar overall shoot growth when tree level measurements of "on" and "off" years are compared (Stevenson et al., 2000), suggesting again the complexity of inter-organ resource distribution in this species.

Since carbon allocation responds to a number of physiological and environmental factors (Spann et al., 2009) that are very difficult to isolate in field trials, models that integrate such factors and simulate growth patterns and competition among organs have been developed (Bruchou and Genard, 1999; Vivin et al., 2002; Witowski, 1997; Bassow et al., 1990). In these models, growth is expressed as the interaction among physiological processes such as photosynthesis, respiration, translocation and carbon accumulation that can be observed at the cell, organ or plant organization level.

In the case of pistachio, Marino et al. (2018a) characterized the seasonal dynamics of carbon gain for bearing and non-bearing branches under rainfed conditions. This study showed that integrating information at the organ-scale (from a leaf to a branch level) and temporal-scale (from an instantaneous rate to the seasonal cumulative trend) is critical to identify key productive processes associated with alternate bearing.
Marra et al. (2009) characterized the respiration of pistachio organs and its response to temperature changes.

In this study, we characterize the seasonal dynamics of dry matter accumulation for the different organs of a typical pistachio branch with high crop load and no crop load. We then integrate this information with the assimilation and respiration sub-models previously described by Marino et al. (2018a) and Marra et al. (2009) to model, for the first time, the seasonal carbon budget of a pistachio branch as a function of crop load. The simulations obtained with the model are used to discuss some physiological aspects of bearing patterns in pistachio in relation to seasonal resource availability and use.

\section{Material and methods}

\subsection{Experimental location and environmental data}

The growth measurements were performed in 2009 on five 24-yearold uniform Pistacia vera (L.) cv. Bianca trees grafted onto P. terebinthus (L.) rootstocks, spaced at $5 \times 6 \mathrm{~m}$, in a commercial orchard in the inland of Sicily (Italy; $37^{\circ} 26^{\prime} 02^{\prime \prime} \mathrm{N}, 14^{\circ} 03^{\prime} 12^{\prime \prime} \mathrm{E}, 370 \mathrm{~m}$ a. s. 1.). Trees were rainfed and received routine commercial horticultural care. The soil was $33.8 \%$ sand, $15.1 \%$ silt, and $51.1 \%$ clay.

Meteorological data were acquired with a weather station installed in the experimental field. Hourly air temperature $\left(\mathrm{T}_{\text {env }}\right)$, environmental photosynthetic photon flux density $\left(\mathrm{I}_{\text {env }}\right)$ and cumulative precipitation were measured using a MP100 sensor (Rotronic Instruments Ltd., UK), a Li-190 Quantum sensor (Li-Cor Biosciences, Nebraska, USA) and a ARG100 precipitation sensor (Campbell Scientific Inc., Utah) respectively. The sensors were connected to a CR1000 (Campbell Scientific Inc., Utah) data logger that recorded data throughout the growing season.

The photosynthetic photon flux density (PPFD) incident on each leaf of a branch ( $\mathrm{I}_{\text {leaf }}$ ) was measured with previously calibrated silicon photosensors (silicon NPN phototransistor, model DFT02, Micropto, Italy) placed on the adaxial surface of the apical leaflet of each leaf of a branch as described in Marino et al. (2018a). The $\mathrm{I}_{\text {leaf }}$ data collected were then recalculated as a percentage of the corresponding $\mathrm{I}_{\mathrm{env}}$ values measured at the same time in the meteorological station $\left(\mathrm{I}_{\text {perc }}\right)$. Data were collected for 30 days, from the 16th to the 22nd of July 2009 and from the 4th to the 26th of August 2009.

\subsection{Growth measurements}

Two types of measurements were performed: 1) non destructive infield measurements on labelled branches monitored through the entire season, and 2) destructive measurements on branches that were cut and brought to the lab.

For the non destructive measurements, two bearing and two nonbearing branches with current- and previous-year growth were selected and labeled in each tree. The "on" or bearing selected branches had $\sim 4$ infructescences (clusters) and the "off" or non-bearing branches had no infructescences. Starting at leaf out (that happened the 3rd of April), 22 days before full bloom (DBFB) (full bloom happened the 25th of April), the following parameters were measured biweekly: length and basal diameter of the current year shoot, number of leaves, number of leaflets per leaf, number of infructescences, and number of fruits per infructescence.

For the destructive measurements, other two bearing ( $\sim 4$ infructescences) and two non-bearing branches per tree were selected every 2 to 3 weeks, cut and brought to the laboratory and, in addition to the same measurements made in the field, fresh weight (FW) and dry weight (DW) were measured. For the DW measurement, samples were placed in a ventilate oven at $60{ }^{\circ} \mathrm{C}$ until no changes in mass were recorded.

Destructive measurements were used to characterize, by extrapolation, changes in DW of the branches in the field. In particular, shoot length was correlated to shoot dry weight, and the obtained linear 
regression was used to estimate the dry weight of the current-year shoots of the labeled branches in the field. The average leaflet dry weight for each bearing and non-bearing sampled branch was plotted against time (expressed in DAFB) and adjusted using a non-linear regression methodology developed by Marra et al. (2009). The obtained relationship was used to estimate the total leaf dry weight of the branches monitored in the field. Finally, the average dry weight of the fruits and rachises of the sampled branches was also determined. The obtained values were used to estimate the fruit and rachis dry weight of the branches monitored in the field. Statistical analysis was carried out using Systat program (SYSTAT Software 12 Inc., Chicago, IL). Sigmaplot program was used to produce the graphs (SYSTAT Software 12 Inc., Chicago, IL).

\subsection{Description of the model}

The simulation model was made using Stella ${ }^{\circledR}$ dynamic modeling software. The time integration of the model was set at 1 hour, and the simulations started at $35 \mathrm{DBFB}$, corresponding to 12 days before leaf out, and finished at 161 DAFB, 37 days after harvest that was at 124 DAFB. The simulation model consists of three sub-models, one describing assimilation processes, one describing respiration processes and one describing growth and allocation processes (Fig. 1).

The seasonal carbon budget (CB) of a branch is given by the differences between the main input, i.e. the total amount of carbon assimilated (A), and the different outputs, i.e. the total amount of carbon used for respiration $(R)$ and growth $(G)$ :

$C B=A-(R+G)$

Considering the different organs within a branch separately, eq. (1) becomes:

$C B=A-R_{\text {Leaves }+} R_{\text {Fruits }+} R_{\text {Shoot }+} G_{\text {Leaves }+} G_{\text {Fruits }+} G_{\text {Shoot }}$

where $\mathrm{A}$ is the carbon assimilated by all the leaves in the branch, $\mathrm{R}_{\text {Leaves }}$ is the carbon respired by all the leaves in the branch, $\mathrm{G}_{\text {Leaves }}$ is the carbon fixed for the growth of all the leaves in the branch, $R_{\text {Shoot }}$ is the carbon respired by the shoot, $\mathrm{G}_{\text {Shoot }}$ is the carbon fixed for the growth of the shoot, $\mathrm{R}_{\text {Fruits }}$ is the carbon respired by all the fruits in the branch and $\mathrm{G}_{\text {Fruits }}$ is the carbon fixed for the growth of all the fruits in the branch.

The assimilation sub-model (A) has been previously published by Marino et al., 2018a. Briefly, we used the non-rectangular hyperbola model proposed by Marshall and Biscoe (1980) to describe the response of photosynthesis to incoming radiation:

$P_{N}=\frac{\alpha I+P_{N \max }-\sqrt{\left(\alpha I+P_{N \max }\right)^{2}-4 \alpha I P_{N \max } \theta}}{2 \theta}-R_{D}$

where $\mathrm{P}_{\mathrm{N}}$ is leaf net photosynthesis $\left(\mu \mathrm{mol} \mathrm{m} \mathrm{m}^{-2} \mathrm{~s}^{-1}\right), \alpha$ is the apparent quantum yield ( $\mathrm{mol}\left(\mathrm{CO}_{2}\right) \mathrm{mol}$ (photons) $\left.{ }^{-1}\right), \mathrm{P}_{\mathrm{Nmax}}$ is the maximum photosynthetic capacity $\left(\mu \mathrm{mol} \mathrm{m} \mathrm{m}^{-2} \mathrm{~s}^{-1}\right.$ ), I is the photosynthetic photon

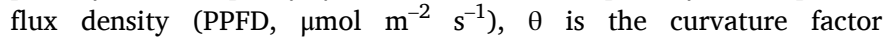

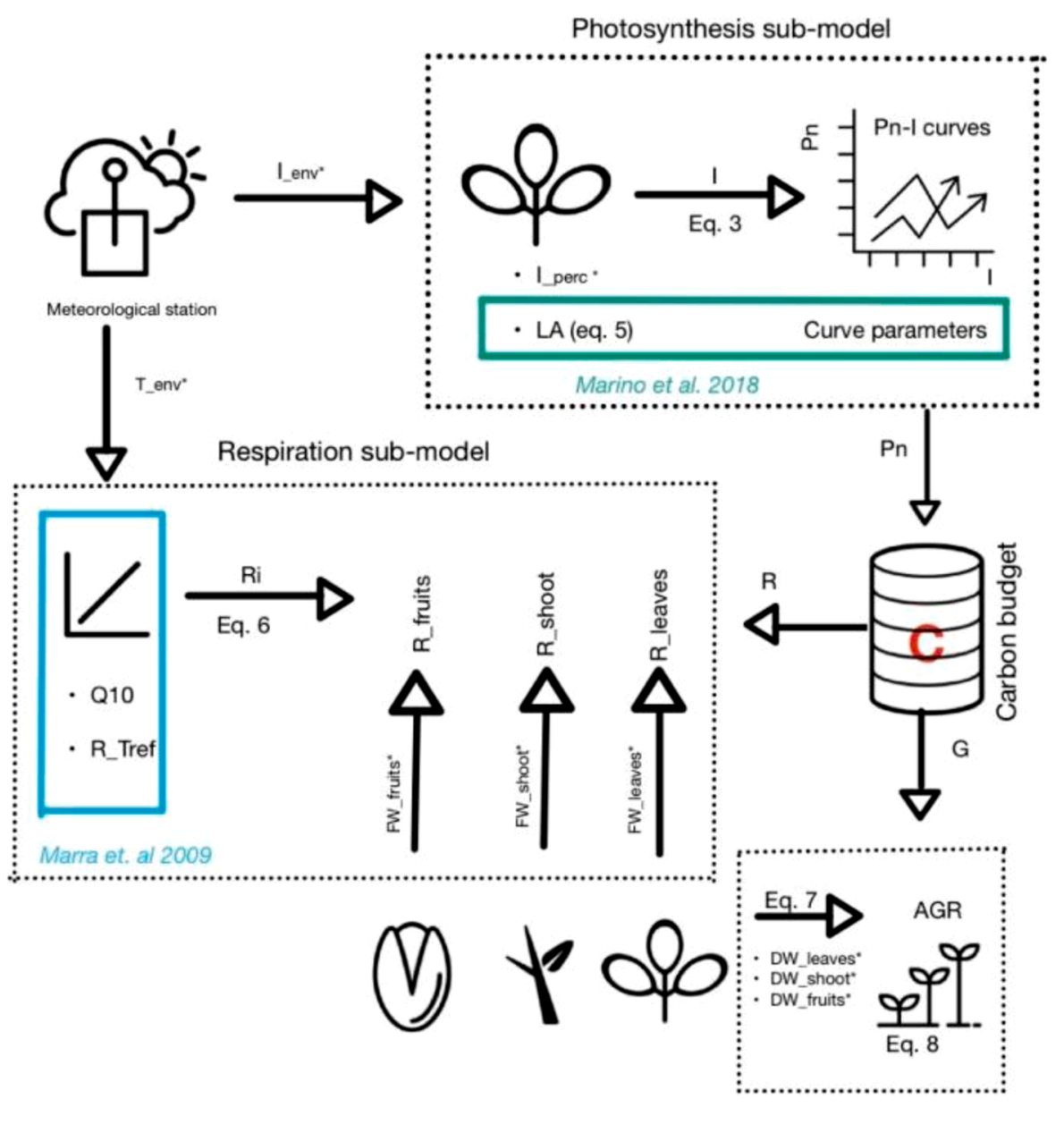

Growth sub-model

Fig. 1. Schematic representation of the branch carbon budget model, divided into the sub-models photosynthesis or assimilation (A), respiration (R) and growth (G). Refer to the text and Table 1 for the meaning of the different acronyms and the equations. Asterisks refer to newly measured data, while data obtained from previously published studies are highlighted with colored blocks. 
(dimensionless), and $R_{D}$ is dark respiration $\left(\mu \mathrm{mol} \mathrm{m} \mathrm{m}^{-2} \mathrm{~s}^{-1}\right)$.

The following parameters, reported by Marino et al. (2018a) per each phenological stage of pistachio, were used to fit equation 3:

- for Stage I ( $<35$ DAFB): $\mathrm{P}_{\mathrm{Nmax}}=15.09 \mu \mathrm{mol} \mathrm{m}^{-2} \mathrm{~s}^{-1} ; \alpha=0.027 \mathrm{~mol}$ $\mathrm{mol}^{-1} ; \mathrm{R}_{\mathrm{D}=} 2.86 \mu \mathrm{mol} \mathrm{m}^{-2} \mathrm{~s}^{-1} ; \theta=0.69$.

- for Stage II ( $>35$ DAFB and $<91$ DAFB): $\mathrm{P}_{\mathrm{Nmax}}=19.39 \mu \mathrm{mol} \mathrm{m}^{-2} \mathrm{~s}^{-1}$; $\alpha=0.033 \mathrm{~mol} \mathrm{~mol}^{-1} ; \mathrm{R}_{\mathrm{D}=1.45 \mu \mathrm{mol} \mathrm{m}}^{-2} \mathrm{~s}^{-1} ; \theta=0.89$.

- for Stage III (>91 DAFB): $\mathrm{P}_{\mathrm{Nmax}}=12.78 \mu \mathrm{mol} \mathrm{m}^{-2} \mathrm{~s}^{-1} ; \alpha=0.027 \mathrm{~mol}$ $\mathrm{mol}^{-1} ; \mathrm{R}_{\mathrm{D}=0.44 \mu \mathrm{mol} \mathrm{m}} \mathrm{s}^{-1} ; \theta=0.79$.

The PPFD incident on each one of the $n$ leaves of the shoot $\left(I_{\text {leaf } n}\right)$ was calculated as:

$I_{\text {leaf } \_n}=I_{\text {env }} * I_{\text {perc } \_n}$

where $\mathrm{I}_{\mathrm{env}}$ is the environmental radiation measured with the meteorological station installed in the orchard, and $I_{\text {perc } n}$ is the percentage of $I_{\text {env }}$ intercepted by each leaf of the branch (see subheading 2.2).

The instantaneous $\mathrm{P}_{\mathrm{N}}$ per each leaf was multiplied by the photosynthetically active leaf area $\left(\mathrm{LA}_{\text {leaf }}\right)$ to obtain the leaf instantaneous assimilation rate $\left(\mathrm{P}_{\text {Nleaf }}\right)$. $\mathrm{LA}_{\text {leaf }}$ seasonal evolution was calculated using the following sigmoid function proposed by Marra et al. (2009):

$y=\frac{a}{1+e^{\left(\frac{x-b}{c}\right)}}$

where $y$ is the leaf area $\left(\mathrm{m}^{2}\right), \mathrm{x}$ is the time in days from full bloom, a is the asymptote of the function, $b$ represents the value (days) at which the function is $50 \%$ of its width and c defines the shape of the curve (dimensionless). The values of $\mathrm{a}, \mathrm{b}$ and $\mathrm{c}$ for bearing ( $a=0.0139 ; b=$ $13.5 ; c=3.9)$ and non-bearing branches ( $a=0.0163 ; b=12.8 ; c=4.9)$ previously published by Marino et al. (2018a) for the same branches were used first to fit the equations. The shoot instantaneous $\mathrm{P}_{\mathrm{N}}$ rate was then calculated as the sum of the instantaneous $\mathrm{P}_{\mathrm{N}}$ of each leaf.

The respiration sub-model (R) was built based on the information developed by Marra et al. (2009). The instantaneous rate of respiration

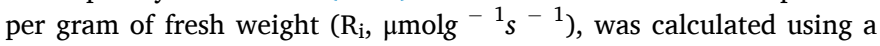
non-linear function (Amthor, 1989; Marchi et al., 2007) that describes the exponential response of respiration rate to temperature:

$R_{i}=R_{\text {Tref }} \cdot Q_{10}^{\left(T_{\text {env }}-T_{\text {ref }}\right) / 10}$

where $R_{\text {Tref }}$ is the respiration at a reference temperature $\left(\mathrm{T}_{\text {ref }}\right)$ of $20^{\circ} \mathrm{C}$ and $\mathrm{Q}_{10}$ denotes the factor by which the respiration rate differs for a temperature interval of $10{ }^{\circ} \mathrm{C}$. Both values were obtained from Marra et al. (2009) and are reported in Table 2.

$\mathrm{T}_{\text {env }}$ is the hourly environmental temperature and it was measured with the meteorological station installed in the orchard. The instantaneous values of respiration $\left(R_{i}\right)$ were then multiplied for the fresh weight of the different organs $\left(\mathrm{FW}_{\text {Leaves }}, \mathrm{FW}_{\text {Shoot}}, \mathrm{FW}_{\text {Fruits }}\right.$ ) to obtain the organ specific respiration rates through the season $\left(R_{\text {Leaves}}, R_{\text {Shoot }}\right.$ and $\left.R_{\text {Fruits }}\right)$.

The growth sub-model (G) calculated the $\mu \mathrm{mol}$ of $\mathrm{C}$ used for the growth of the different organs of the branch (shoot, leaves and fruits). First, the dry weights of the organs measured through the season (as reported in subheading 2.2) were fit with different equations to obtain daily dry weight values through the season. Leaf and shoot dry weight were fit using the eq. (5) reported by Marra et al. (2009). For infructescence dry weight, we used a smoothed spline function to avoid assumptions regarding the pattern of infructescence dry weight.

The dry weights were transformed in $\mu \mathrm{mol}$ of $\mathrm{C}$ using the following equation:

$C_{t i}(\mu m o l)=\frac{D W_{t i} \cdot 0.45}{12} \cdot 10^{6}$

Table 2

Coefficients used to fit eq. (6), obtained from Marra et al. (2009).

\begin{tabular}{llll}
\hline Organs & $\mathrm{DAFB}$ & $\mathrm{RT}_{\text {ref }}\left(\mathrm{nmol} s^{-1}\right)$ & $\mathrm{Q} 10$ \\
\hline Vegetative & -4 & 15.35 & 1.23 \\
& 9 & $12.69)$ & 1.64 \\
& 19 & 8.69 & 1.42 \\
& 22 & 6.14 & 1.18 \\
Reproductive & $\geq 36$ & 1.58 & 2.64 \\
& -4 & 10.4 & 1.97 \\
& 9 & 6.58 & 1.58 \\
& $\geq 22$ & 0.25 & 3.50 \\
\hline
\end{tabular}

Table 1

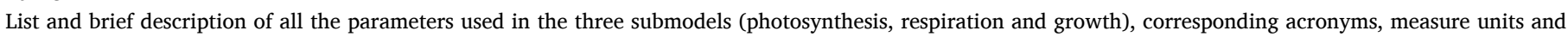
sources of the information.

\begin{tabular}{|c|c|c|c|c|}
\hline Submodel & Description & Acronym & Unit & Source \\
\hline \multirow[t]{10}{*}{ Assimilation (A) } & Leaf area & LA & $\mathrm{m}^{2}$ & Marino et al., 2018a \\
\hline & PPFD environment & $\mathrm{I}_{\text {env }}$ & $\mu \mathrm{mol} m^{-2} \mathrm{~s}^{-1}$ & Measured \\
\hline & Leaf PPFD interception & $I_{\text {perc }}$ & $\%$ & Measured \\
\hline & PPFD incident on the leaf & $\mathrm{I}_{\text {leaf }}$ & $\mu \mathrm{mol} \mathrm{m}^{-2} \mathrm{~s}^{-1}$ & $\left(\mathrm{I}_{\text {env }}\right) *(\mathrm{I})$ \\
\hline & Instantaneous net photosynthesis & $P_{n}$ & $\mu \mathrm{mol} \mathrm{m}{ }^{-2} \mathrm{~s}^{-1}$ & $P_{\mathrm{N}}=\frac{\alpha \mathrm{I}+P_{\mathrm{N} \max }-\sqrt{\left(\alpha \mathrm{I}+P_{\mathrm{N} \max }\right)^{2}-4 \alpha \mathrm{I} P_{\mathrm{Nmax}} \theta}}{-R_{\mathrm{D}}}$ \\
\hline & Apparent quantum yield & $\alpha$ & $\mathrm{mol}^{-1}$ & Marino et al., 2018a $\quad 2 \theta$ \\
\hline & Maximum photosynthetic capacity & $P_{\text {Nmax }}$ & $\mu \mathrm{mol} \mathrm{m}{ }^{-2} \mathrm{~s}^{-1}$ & Marino et al., 2018a \\
\hline & Curvature factor & $\theta$ & Dimensionless & Marino et al., 2018a \\
\hline & Dark respiration & $R_{\mathrm{D}}{ }^{1}$ & $\mu \mathrm{mol} \mathrm{m}{ }^{-2} \mathrm{~s}^{-}$ & Marino et al., 2018a \\
\hline & SHOOT ASSIMILATION & & $\mu \mathrm{mol} / \mathrm{h}$ & $\mathrm{Pn}^{*}(\mathrm{LA}) * 3600$ \\
\hline \multirow[t]{7}{*}{ Respiration(R) } & Air temperature & $\mathrm{T}_{\text {env }}$ & ${ }^{\circ} \mathrm{C}$ & Measured \\
\hline & $\mathrm{Q}_{10}$ & & Dimensionless & Marra et al., 2009 \\
\hline & Reference temperature & $\mathrm{T}_{\text {ref }}$ & $20{ }^{\circ} \mathrm{C}$ & Predetermined \\
\hline & Fresh weight & FW & $\mathrm{g}$ & Measured \\
\hline & Resp_ref $\left(20^{\circ} \mathrm{C}\right)$ & $\mathrm{R}_{\text {Tref }}$ & $\mu \mathrm{mol} g^{-1} \mathrm{~s}^{-1}$ & Marra et al., 2009 \\
\hline & Instantaneous respiration & $\mathrm{R}_{\mathrm{i}}$ & $\mu \mathrm{mol} g^{-1} \mathrm{~s}^{-1}$ & $\mathrm{R}_{\text {Tref }}{ }^{*} \mathrm{Q}_{10} \wedge\left(\left(\mathrm{T}_{\mathrm{env}}-\mathrm{T}_{\mathrm{ref}}\right) / 10\right)$ \\
\hline & ORGAN RESPIRATION & & $\mu \mathrm{mol} h^{-1}$ & $(\mathrm{Ri}) *(\mathrm{FW}) * 3600$ \\
\hline \multirow[t]{6}{*}{ Growth(G) } & Dry weight & DW & $\mathrm{g}$ & Measured \\
\hline & $\%$ of carbon per DW & & 0.45 & Negi et al., 2003 \\
\hline & $\mathrm{C}$ mass weight & & $12 \mathrm{~g}$ & Predetermined \\
\hline & $\mu \mathrm{mol} \mathrm{C}$ organs & $\mathrm{C}$ & $\mu \mathrm{mol}$ & $\left.\left.\left(\mathrm{DW}^{*} 0.45\right) / 12\right)^{*} 1,000,000\right)$ \\
\hline & Absolute growth rate & AGR & $\mu \mathrm{mol} \mathrm{h}^{-1}$ & $\mu$ mol $C$ organs $\mathrm{f}(\mathrm{x})$ time \\
\hline & ORGAN GROWTH & & $\mu \mathrm{mol} \mathrm{h}^{-1}$ & $\Sigma$ AGR \\
\hline
\end{tabular}


where $t_{i}$ is the time of the sampling $i$ expressed in DAFB, DW ${ }_{t i}$ is the dry weight of each organ at $t_{i}, 0.45$ are the grams of carbon per gram of dry weight (Negi et al., 2003) and 12 is carbon molar mass.

The obtained $\mathrm{C}_{\mathrm{ti}}$ values were used to calculate the absolute growth rate (AGR, $\mu \mathrm{mol} \mathrm{day}{ }^{-1}$ ) as follows:

$A G R=\frac{\left(C_{t i+1}-C_{t i}\right)}{\left(t_{i+1}-t_{i}\right)}$

where $C_{t i}$ and $C_{t i+1}$ are $\mu \mathrm{mol}$ of carbon at two consecutive sampling dates, and $t_{i}$ and $t_{i+1}$ are the days between the two sampling dates.

AGR values were then used to calculate the rates of $C$ used for growth.

\subsection{Simulations}

The model was used to simulate the carbon budget of branches with different crop load. In particular, the simulations were made for branches with 3, 2 and 1 clusters. The biometric and physiological data of the measured branches with $\sim 4$ clusters were used to simulate the carbon budget of branches with 3 and 2 clusters. The biometric and physiological data of the measured branches with no clusters were used to simulate the carbon budget of branches with 1 cluster.

\section{Results}

\subsection{Environmental data}

The climate was typical of Mediterranean areas with three dry months (from June to September). Precipitation started at the end of August-beginning of September. The minimum air temperature ranged from 10 to $20^{\circ} \mathrm{C}$ and the maximum air temperature ranged from $20^{\circ} \mathrm{C}$ to $40{ }^{\circ} \mathrm{C}$ (Fig. 2).

Light interception by leaves $\left(\mathrm{I}_{\text {perc }}\right.$ ) started around 6 am and showed one main peak in the morning, between 7 and $8 \mathrm{am}$. At this time, leaves intercepted between 50 and $100 \%$ of the environmental radiation $\left(\mathrm{I}_{\mathrm{env}}\right)$, depending on their position within the branch (Fig. 3). The lowest values of $\mathrm{I}_{\text {perc }}$ were recorded between $11 \mathrm{am}$ and $2 \mathrm{pm}$, and ranged between 10 and $50 \%$ of $\mathrm{I}_{\mathrm{env}}$. Based upon the position along the shoot, some leaves showed an increase in light interception in the afternoon, at around 4 to $5 \mathrm{pm}$, with peaks up to $80 \%$ of $\mathrm{I}_{\mathrm{env}}$.

\subsection{Growth measurements}

The studied bearing and non-bearing branches had a similar number of leaves per shoot and leaflets per leaf ( 6 and $\sim 4$, respectively) as measured at 40 DAFB (Table 3). On average, bearing branches had 4 clusters with 14 fruits each. Despite bearing branches tended to have longer shoots than non-bearing branches, the difference was not statistically significant as affected by a large error standard. Non-bearing branches had, however, a significantly larger basal diameter than bearing branches. Entire shoot dry weight was similar for both types of branches.

The relationship between shoot length and shoot dry weight measured through the entire season provides a better overview of the differences among shoots within and between branch types (Fig. 4). This relationship was linear, highly significant and with low dispersion. Nonbearing branches tended to have heavier shoots per unit length than bearing branches, in line with their greater basal diameter. However, among bearing branches there was a higher number of long shoots (more than $10 \mathrm{~cm}$ ).

Leaf dry weight started to increase few days before full bloom and reached maximum values slightly after 50 DAFB (Fig. 5). Maximum leaf dry weight was higher in the non-bearing $(2.7 \mathrm{~g})$ versus the bearing branches $(2.3 \mathrm{~g})$. Leaf drop reduced leaf number per branch in the nonbearing branches from 7 to 6 starting at 130 DAFB, while in the bearing branches leaf drop started at 98 DAFB and only 2 leaves remained on the branches from 130 DAFB forward.

Infructescence dry weight increased rapidly starting after full bloom, and continued to increase through all the season (Fig. 6). A slight decrease in dry weight accumulation was observed around 40 and 100 DAFB. After this latter slow-down, infructescence dry weight increased sharply until harvest, when weighed $16 \mathrm{~g}$.

The absolute growth rate (AGR) seasonal pattern for the different organs of the branch shows a peak around 35 DAFB, when leaves are expanding and fruits enlarging; the AGR of the leaves is $800 \mu \mathrm{mol} h^{-1}$ and the AGR of one infructescence is $200 \mu \mathrm{mol} \mathrm{h}{ }^{-1}$ (Fig. 7). The AGR of four infructescences overpasses that of the leaves starting at bloom, when $\sim 200-300 \mu \mathrm{mol} h^{-1}$ are needed for reproductive growth. Even later, at 35 DAFB, during the leaves' AGR peak, the AGR of four infructescences is $\sim 200 \mu \mathrm{mol} h^{-1}$ higher than that of the leaves from the bearing branch. During the rest of the season, only the infructescences continue to show evident growth, with another AGR peak at

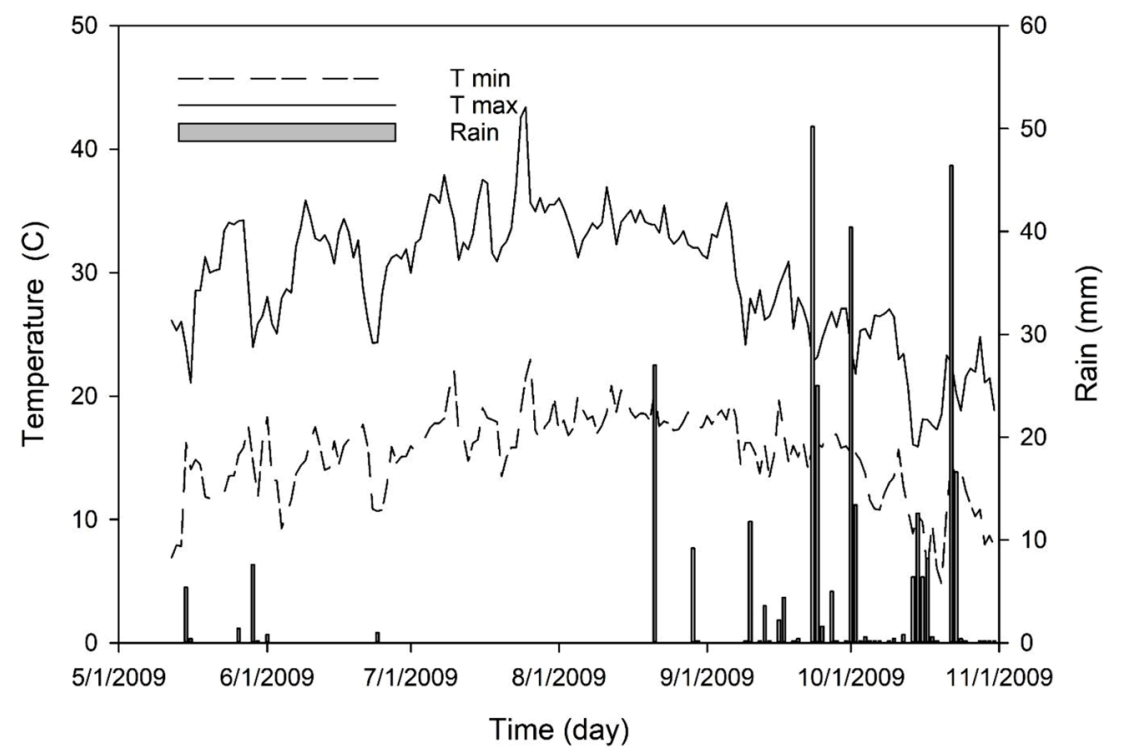

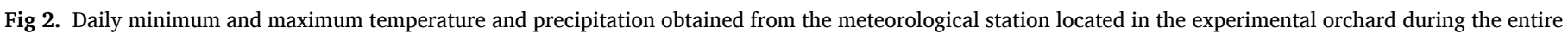
reproductive season. 

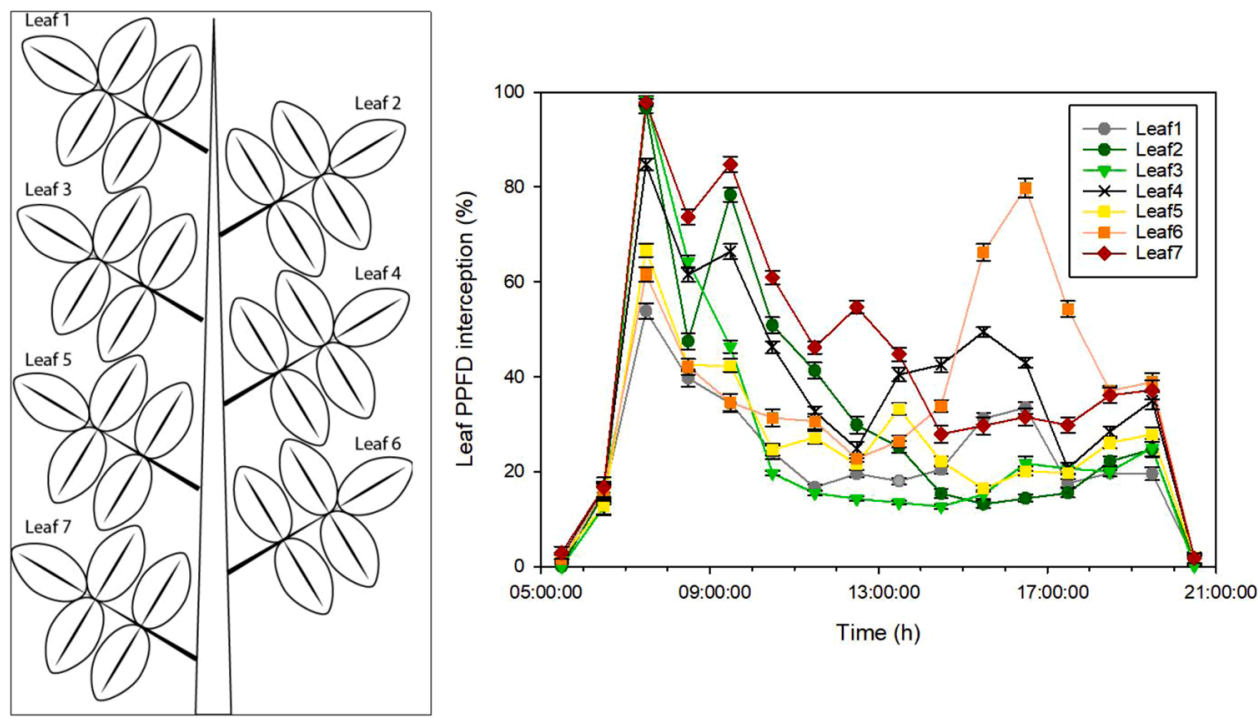

Fig. 3. Average daily dynamics (hourly) of the fraction (\%) of environmental PPFD intercepted by each leaf of a branch ( $\mathrm{I}_{\text {perc }}$ ) with respect to the position in the branch. Each point is the average of measurements performed for 30 days during July and August 2019. Vertical bars represent the standard error of the means ( $n$ $=30$ ).

Table 3

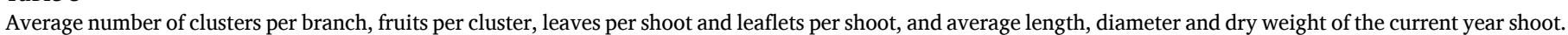

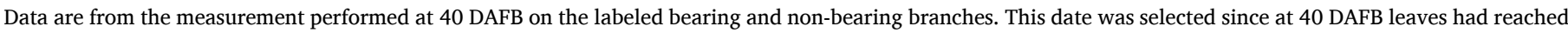

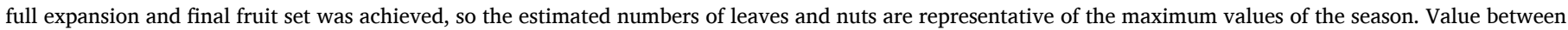
bracket is the standard error of the mean $(n=20)$.

\begin{tabular}{|c|c|c|c|c|c|c|c|}
\hline & No. clusters & No. fruits per cluster & Shoot length $(\mathrm{cm})$ & Shoot basal diameter $(\mathrm{cm})$ & Shoot dry weight (g) & No. leaves per shoot & No. leaflets per shoot \\
\hline Bearing & $4.3( \pm 0.9)$ & $13.97( \pm 3.3)$ & $8.75( \pm 6.8)$ & $0.79( \pm 0.1)$ & $0.91( \pm 0.3)$ & $6.1( \pm 0.8)$ & $24.3( \pm 0.9)$ \\
\hline Non bearing & - & - & $5.14( \pm 4.6)$ & $0.87( \pm 0.1)$ & $0.82( \pm 0.21)$ & $6.7( \pm 0.1)$ & $28.9( \pm 0.8)$ \\
\hline
\end{tabular}

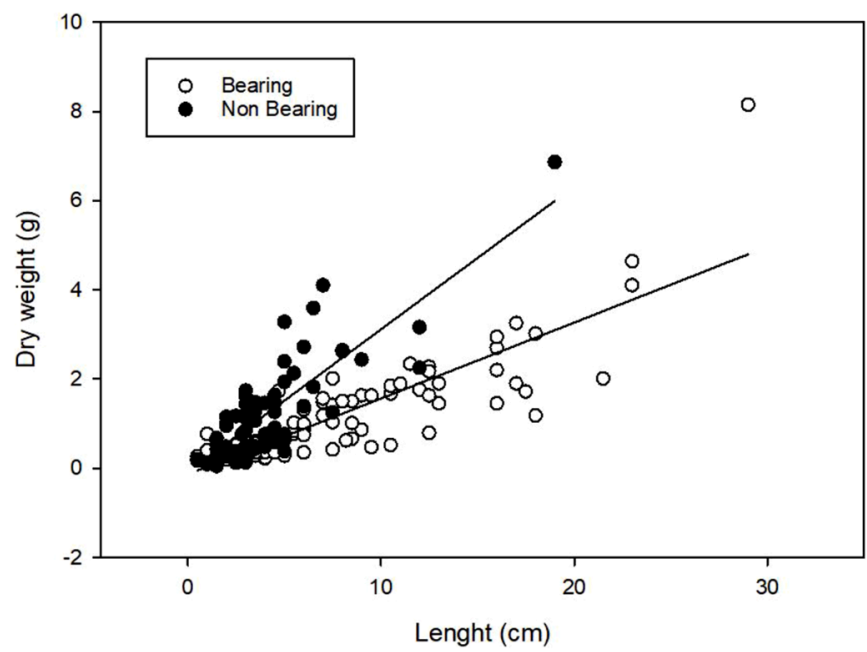

Fig. 4. Relationship between seasonal data of shoot length and dry weight of bearing and non-bearing branches. Parameters of the linear equation $(y=a x+b)$ used for non-bearing branches were: $a=0.3198 ; b=-0.0830 ; \mathrm{r}^{2}=0.70 ; P=$ $<0.0001$. Parameters of the equation for bearing branches were: $a=0.17$; $b=-0.14 ; \mathrm{r}^{2}=0.70 ; P=<0.0001$.

$\sim 100$ DAFB of $1600 \mu \mathrm{mol} h^{-1}$, corresponding to the period of rapid embryo growth. Shoot AGR is irrelevant with respect to the other organs, using only $8 \mu \mathrm{mol} h^{-1}$ at its maximum growth rate that happens around 30 DAFB.

\subsection{Model simulation}

The model developed allows establishing comparisons between the flux of carbon (C; in $\mu \mathrm{mol} \mathrm{day}{ }^{-1}$ ) produced by the branch through photosynthesis (input) and the flux of carbon used to support the entire branch growth and respiration (output) (Fig. 8). At the beginning of the season, the amount of $C$ used to support vegetative and reproductive growth is higher than the amount of $C$ produced by the leaves of a branch. During the first month of growth (until bloom), the branch used an increasing amount of $\mathrm{C}$, up to a rate of $\sim 25,000 \mu \mathrm{mol} \mathrm{C}$ day $^{-1}$ (bearing branch) and $\sim 10,000 \mu \mathrm{mol} \mathrm{C} \mathrm{day}{ }^{-1}$ (non-bearing branch). During this period, $\mathrm{C}$ is mainly used for respiration. However, soon after full bloom, the output fluxes of the bearing branch sharply increased due to a raise in the $\mathrm{C}$ used to sustain reproductive growth. From 10 DAFB until the end of the season, the $\mathrm{C}$ assimilation rate in the non-bearing branch overpassed the rate of $\mathrm{C}$ used. In contrast, the input flux in the bearing branch was higher than the output only between 40 and 100 DAFB, during the stage of shell hardening, when the $C$ request for fruit growth was relatively low, and from 124 DAFB (harvest) forward. The peak of $C$ consumption of $\sim 25,000 \mu \mathrm{mol} \mathrm{C} \mathrm{day}{ }^{-1}$ in the non-bearing branch happens at $35 \mathrm{DAFB}$, while the bearing branch had two peaks, one at 35 DAFB and one at 100 DAFB, both over $40,000 \mu \mathrm{mol} \mathrm{C}$ day $^{-1}$. The assimilation started decreasing around 85 DAFB, and the decrease was smooth and constant for the non-bearing branch, that was still able to fix between 10,000 and $20,000 \mu \mathrm{mol} \mathrm{C} \mathrm{day}{ }^{-1}$ after harvest. In the bearing branches, assimilation decreased sharply from almost 30,000 to less than $10,000 \mu \mathrm{mol} \mathrm{C}$ day $^{-1}$ between 100 and 125 DAFB, in correspondence to the late season peak of $\mathrm{C}$ consumption, and continued to decrease constantly after harvest.

The impact of the crop load on the seasonal carbon budget of the leaves $\left(\mathrm{CB}_{\text {leaves }}\right)$ of a branch can be determined from the model 

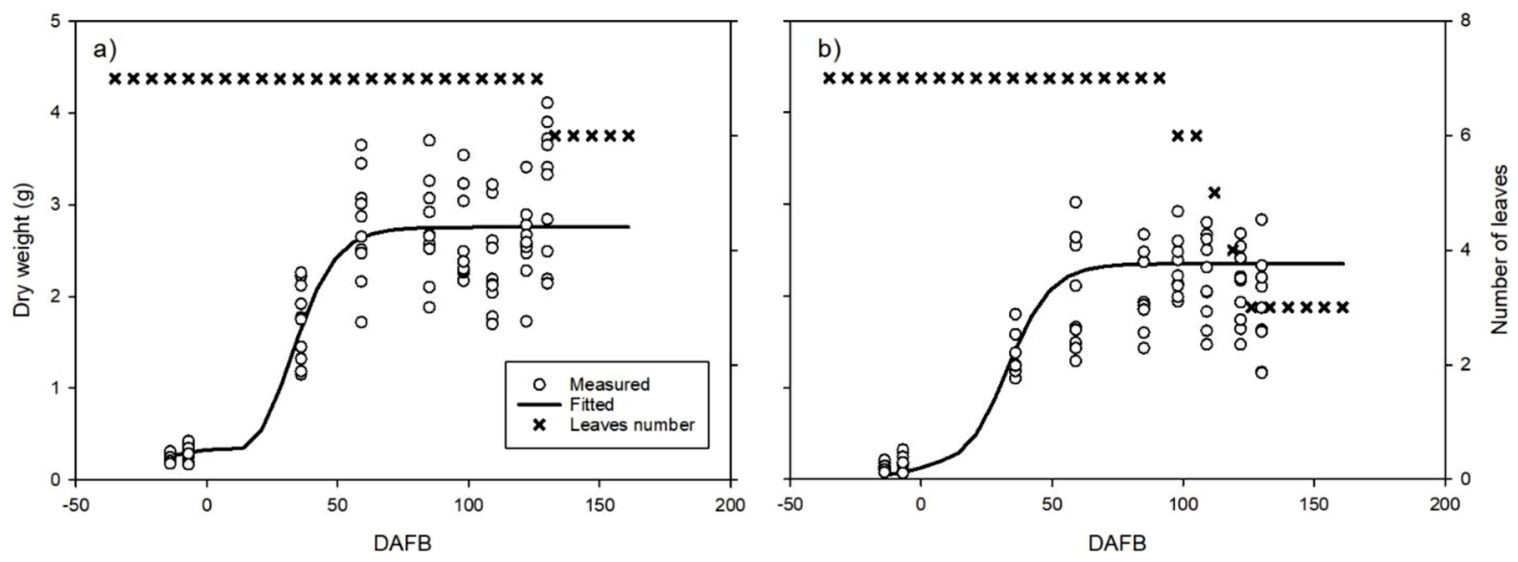

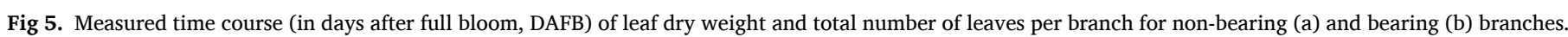

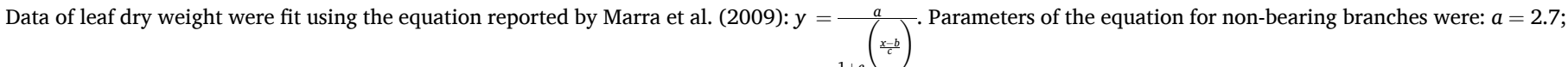
$b=20.4 ; c=12.4 ; \mathrm{r}^{2}=0.79 ; P=<0.0001$. Parameters of the equation for bearing branches were: $a=2.1 ; b=21.5 ; c=12.5 ; \mathrm{r}^{2}=0.83 ; P=<0.0001$.

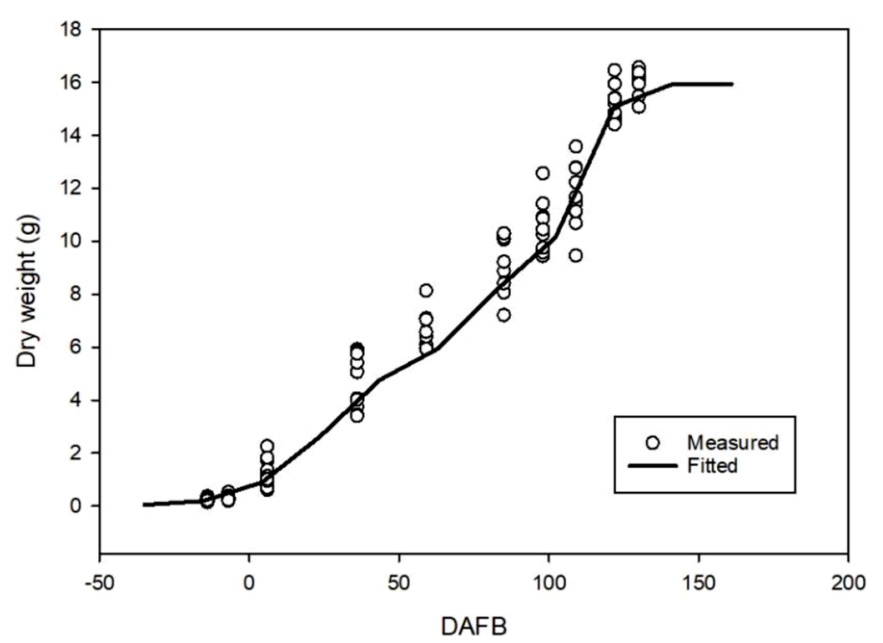

Fig 6. Measured time course (in days after full bloom, DAFB) of infructescence dry weight. Data are fit using a smoothed spline function.

simulations. As an example, Fig. 9 shows $\mathrm{CB}_{\text {leaves }}$ of a high bearing (4 clusters) and a non-bearing (no clusters) branch across the season in comparison to the evolution of the photosynthetically active leaf area (LA). $\mathrm{CB}_{\text {leaves }}$ was calculated as the difference between the $\mathrm{C}$ produced by the leaves of the branch via photosynthesis (A) and the $C$ used to support leaf respiration $\left(\mathrm{R}_{\text {leaves }}\right)$ and growth $\left(\mathrm{G}_{\text {leaves }}\right)$ :

$C B_{\text {leaves }}=A-\left(R_{\text {leaves }}+G_{\text {leaves }}\right)$

The budget shows a negative trend at the beginning of the season, reaching minimum values of $-0.9 \mathrm{~g}$ of $\mathrm{C}$ at 11 DAFB when $39 \%$ of LA expansion was reached in the bearing branch, and $-1.8 \mathrm{~g}$ of $\mathrm{C}$ at 10 DAFB when $36 \%$ of LA expansion was reached in the non-bearing branch. In both branch types, the $\mathrm{CB}_{\text {leaves }}$ did not show a continuous increase until 37 DAFB, when 99\% of LA expansion was reached, becoming positive at 44 DAFB in the bearing and 46 DAFB in the nonbearing branch. At around 100 DAFB, the LA started to decrease. Such decrease was more pronounced in the bearing branch than in the nonbearing branch (33\% reduction and $16 \%$ reduction, respectively). At the end of the season, the bearing branch leaves exported $22 \mathrm{~g}$ of $\mathrm{C}$ to other organs, and the non-bearing branch $30 \mathrm{~g}$.

The whole branch carbon budget reported as seasonal trend in Fig. 10 or as cumulative values at the end of the season in Table 4,

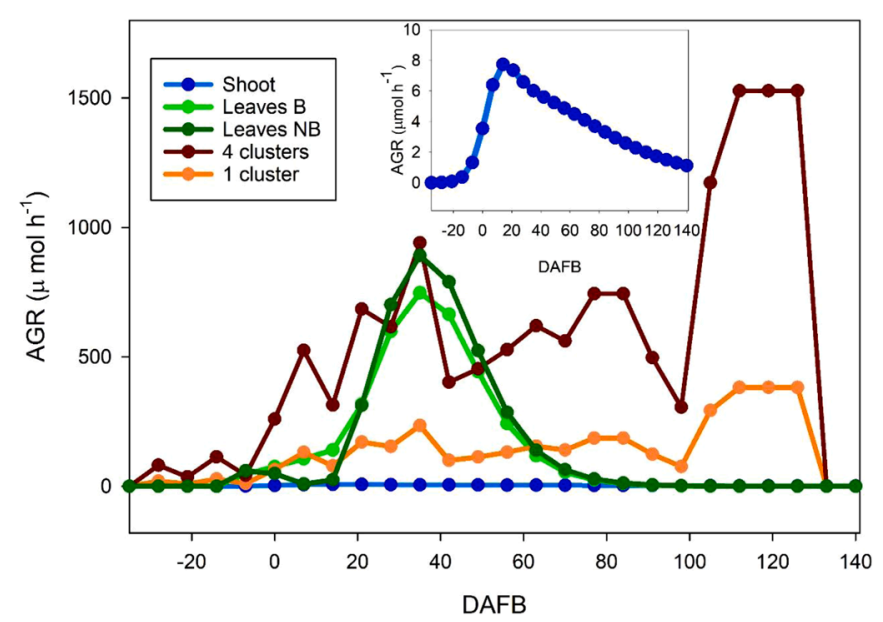

Fig. 7. Seasonal trend of the absolute growth rate (AGR) of the different organs (leaves, shoots and fruits) of bearing (B) and non-bearing (NB) pistachio branches. The dark red line represents the AGR of 4 clusters whereas the orange line the AGR of one single cluster. The inset graph shows a zoom of the AGR of the shoot. Since shoot AGR was the same for bearing and non-bearing branches, only one curve is reported (that of a bearing branch).

reflects the difference between the input, i.e. the total amount of carbon assimilated by the branch, and the various outputs, i.e. the total amount of carbon used for respiration (R) and growth (G), of all the organs of the branch (leaves, shoots and infructescence).

The carbon budget of both non-bearing and bearing branches show a decreasing trend at the beginning of the season. The non-bearing branch carbon budget reached a minimum of $-2.5 \mathrm{~g}$ at around 35 DAFB and then started to increase. In contrast, the decreasing phase continued until 40 DAFB in the bearing branches, reaching values as low as $-6.5 \mathrm{~g}$ in the branch with two clusters and $-12 \mathrm{~g}$ in the branch with four clusters. In the non-bearing branch, the budget became positive at 52 DAFB and after that continued increasing at a constant rate until $\sim 124$ DAFB. The non-bearing branch ended the productive season with a positive carbon budget of $27 \mathrm{~g}$ (Table 4). On the contrary, in the bearing branch the budget became positive at $88 \mathrm{DAFB}$, and only if 2 or less clusters were present. The budget of the branches bearing 3 and 4 clusters was negative through all the season. At around 100 DAFB, bearing branches showed a second decrease in the budget, more pronounced when 4 infructescences were present, followed by a slightly increasing trend after harvest (124 DAFB). Bearing branches ended the 

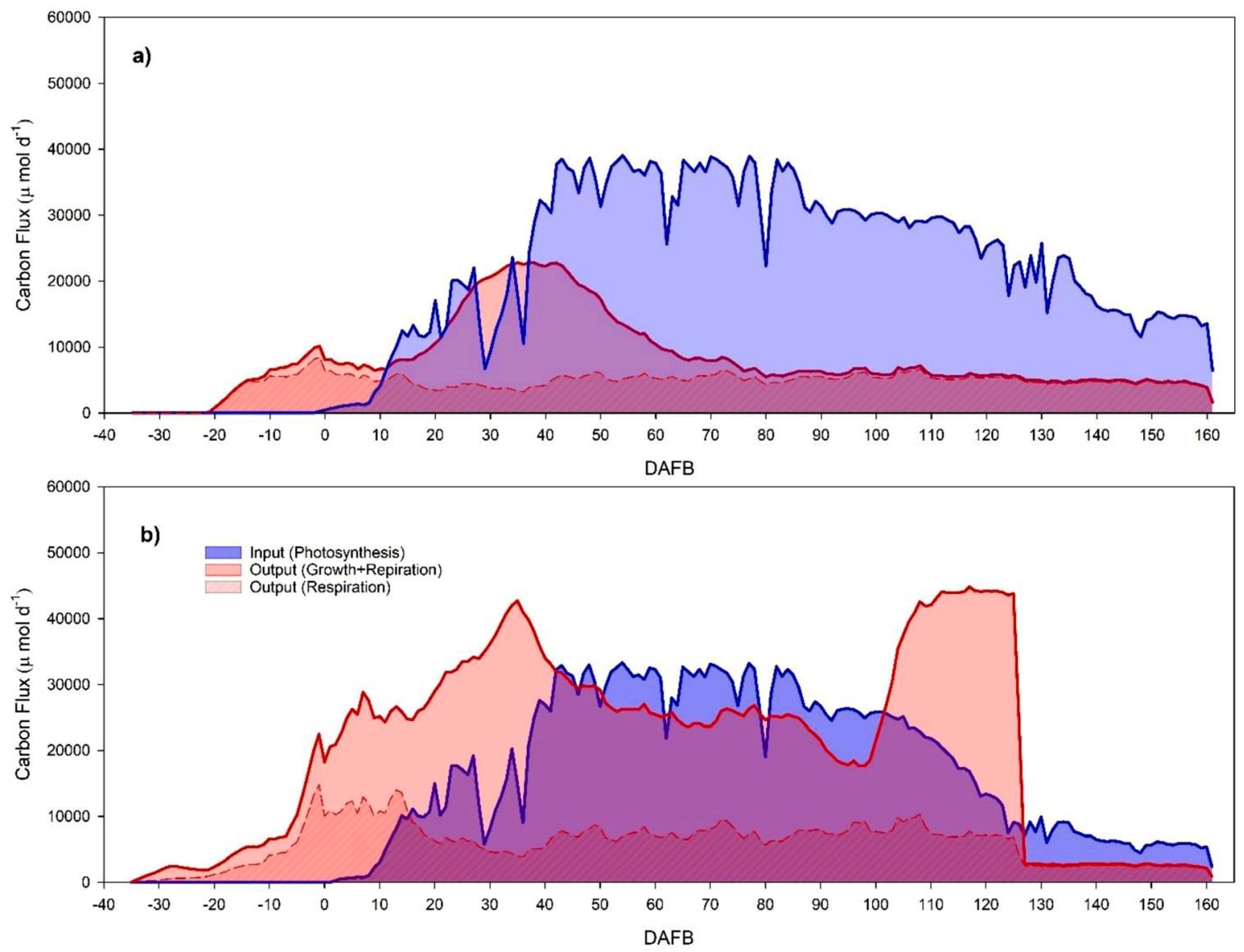

Fig. 8. Seasonal flux of $\mathrm{C}\left(\mu \mathrm{mol} d^{-1}\right)$ produced through photosynthesis (input) and used to support growth and respiration (output) by a non-bearing (a, no clusters) and a bearing (b, 4 clusters) pistachio branch.
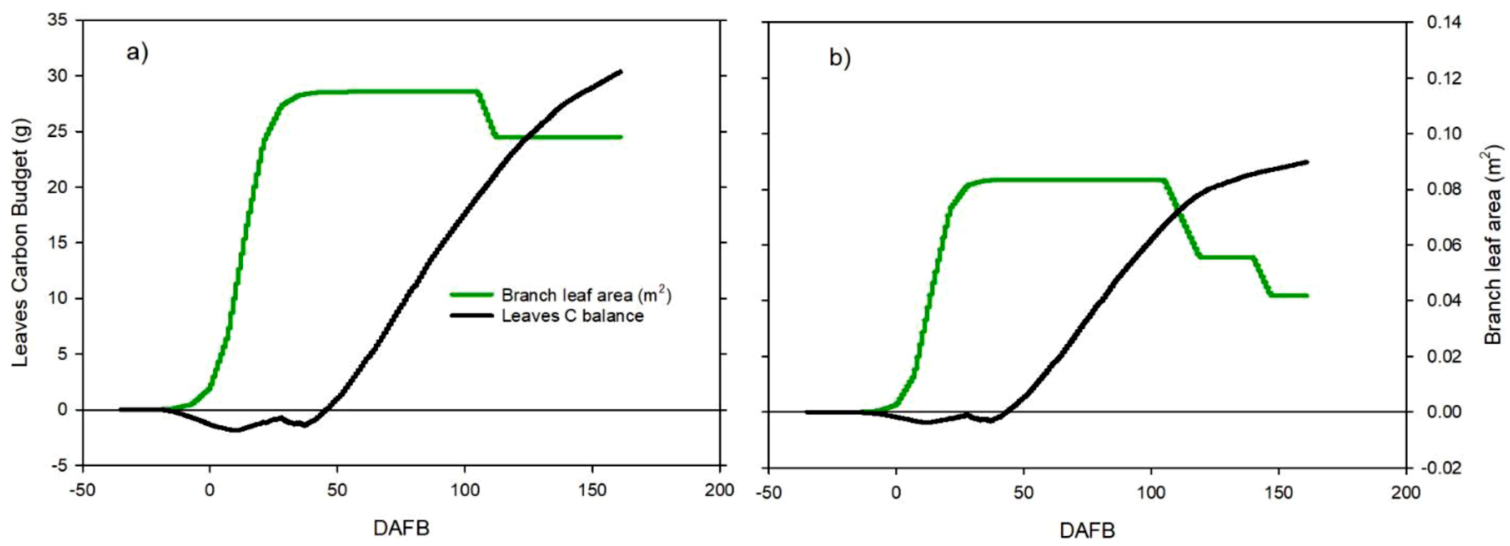

Fig. 9. Simulated seasonal carbon budget ( $\mathrm{g}$ ) of the leaves of a non-bearing (a, no clusters) and a bearing (b, 4 clusters) pistachio branch in comparison to the development of branch photosynthetically active leaf area $\left(\mathrm{m}^{2}\right)$.

season with +18.8 and $+2.6 \mathrm{~g}$ of carbon accumulated in the case only 1 or 2 clusters were present or with -6.4 and $-14.1 \mathrm{~g}$ of carbon in case 3 or 4 clusters were present, respectively (Table 4 ).

\section{Discussion}

Carbon budget models have been developed and widely used to help understand physiological processes associated with resource dynamics and improve orchard management in several crops such as apple (Lakso et al., 1999, 2000, 2004), peach (Allen et al., 2005; Grossman and DeJong, 1994; Lescouret et al. 1998; Genard et al. 1998) and grape

\section{(Lakso et al., 2007; Lakso and Poni, 2005).}

Despite the well known -but still not fully understood- central role that carbon reserves play in pistachio biannual productive cycle (Khezri et al., 2020), and the development of studies aiming to reveal their implications for bearing and productive patterns (Spann et al., 2008; Venmos, 2010; Baninasab and Rahemi, 2006, 2008), nobody attempted, until now, to model the seasonal dynamics of carbon fluxes for this species.

The model proposed in this study confirmed that branch bearing status has a great impact on the dynamics of carbon, and allowed to quantify this impact through the growing season. 


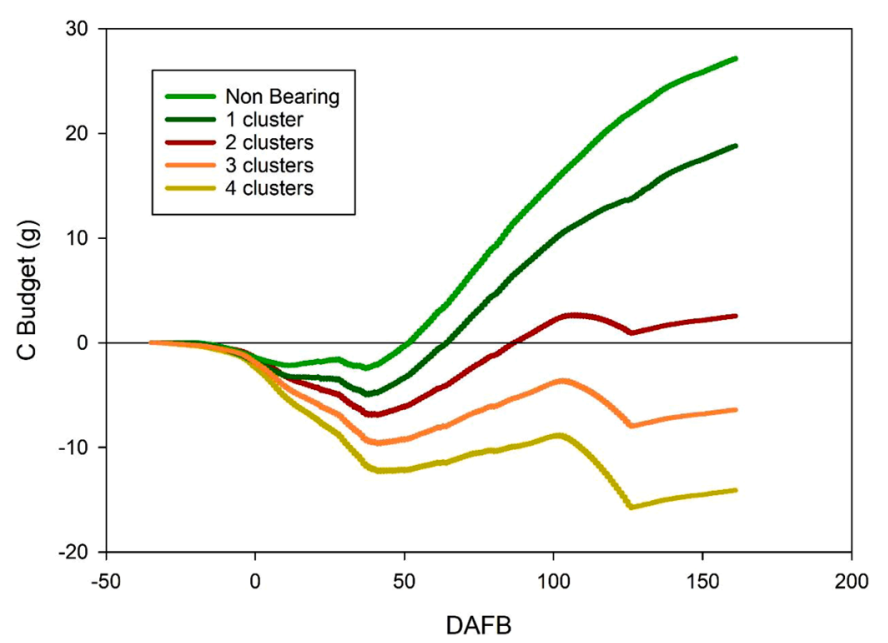

Fig. 10. Simulation of the seasonal trend of the carbon budget of a non-bearing pistachio branch and branches bearing 1, 2, 3 and 4 clusters.

Table 4

Carbon budget (cumulative values at the end of the season $=161$ DAFB) and its different components for a non-bearing pistachio branch and branches bearing $1,2,3$ and 4 clusters.

\begin{tabular}{|c|c|c|c|c|c|}
\hline & $\begin{array}{l}4 \\
\text { clusters }\end{array}$ & $\begin{array}{l}3 \\
\text { clusters }\end{array}$ & $\begin{array}{l}2 \\
\text { clusters }\end{array}$ & $\begin{array}{l}1 \\
\text { cluster }\end{array}$ & $\begin{array}{l}\text { Non- } \\
\text { bearing }\end{array}$ \\
\hline Photosynthesis (g) & 34.8 & 34.8 & 34.8 & 46.4 & 46.4 \\
\hline Respiration (g) & -14.0 & -13.1 & -10.9 & -12.5 & -11.0 \\
\hline $\begin{array}{l}\text { Growth of leaves } \\
(\mathrm{g})\end{array}$ & -6.2 & -6.2 & -6.2 & -6.7 & -6.7 \\
\hline Growth of fruits (g) & -27.2 & -20.4 & -13.6 & -6.8 & 0.0 \\
\hline $\begin{array}{l}\text { Growth of shoots } \\
(\mathrm{g})\end{array}$ & -1.5 & -1.5 & -1.5 & -1.5 & -1.5 \\
\hline Total out (g) & -48.9 & -41.2 & -32.2 & -27.6 & -19.2 \\
\hline Carbon budget (g) & -14.1 & -6.4 & 2.58 & 18.8 & 27.2 \\
\hline
\end{tabular}

At the end of the growing season, a highly bearing branch ( 4 clusters, 56 fruits) had a very negative $\mathrm{C}$ budget of $-14 \mathrm{~g}$ of $\mathrm{C}$, while a nonbearing branch had a positive $\mathrm{C}$ budget with $27 \mathrm{~g}$ of $\mathrm{C}$ accumulated (Table 4). Based on model simulations, branches with 2 or less clusters (max 28 fruits) ended the season with a positive carbon budget. However, all branches were temporary sinks of carbon, since the carbon budget in spring was negative independently from the bearing status (Fig. 10). After this initial decrease in carbon budget, non-bearing branches or branches with one cluster were net sources of carbon for the entire season. Branches with 3 or more clusters never had a positive budget, and were 'self-sufficient' from 40 to 100 DAFB, when the C assimilated by the leaves was enough to satisfy branch needs for growth and respiration (Fig. $8 \mathrm{~b}$ ) but not to recover the depletion happened in the first part of the season. These highly loaded branches were net sinks of carbon at the end of the season, suggesting that the carbon used to sustain their growth and respiration comes from other sources (e.g. reallocation of stored resources and/or of newly assimilated carbon from non-bearing branches). The branch is considered a semi-autonomous unit with regard to carbohydrate availability (Watson and Casper 1984; Sprugel et al., 1991) and further development of this model could study the entire tree as a system of numerous units (DeJong 1999).

It must be pointed out that the model is based on data obtained from branches with either zero or 4 clusters, and the simulations with intermediate crop loads do not take into consideration 1) the impact of gradual changes in sink-source ratio on organs' growth rates, and 2) the different levels of resources that these branches may have. This information should be developed and implemented into the model to improve its accuracy and our knowledge of resource competition among organs within the tree.
The presence of the fruits can affect the $\mathrm{C}$ budget by both being the strongest sink of C (Takeda et al., 1980), and reducing the branch seasonal photosynthetic potential by anticipating leaf senescence (Marino et al., 2018a). Both phenomena are the consequence of competition for resources but in two different moments of the season: an 'early competition', during leaf out, bloom, and nut expansion, until $\sim 35$ DAFB, and a 'late competition', starting around 100 DAFB, when rapid embryo growth for kernel filling takes place.

At the beginning of the season, when leaves are heterotrophs and need more carbon for growing and respiring than what they can assimilate (Figs. 8 and 9), the carbon budget of the branch relies on resources from other organs. The model showed that $\sim 2.5 \mathrm{~g}$ of $\mathrm{C}$ should be available from resource mobilization to support leaf and shoot growth until leaves become autotrophs and able to supply carbon to other demanding organs. Assuming a concentration of starch in the wood of a 1-year-old shoot of $\sim 80 \mathrm{mg} g^{-1} \mathrm{DW}$ in spring (Marra et al. 1997), with an shoot average length of $6 \mathrm{~cm}$, and an average biomass of $0.3 \mathrm{~g}$ of DW per $\mathrm{cm}$ of wood7, we can predict that $\sim 0.14 \mathrm{~g}$ of starch and $\sim 0.06 \mathrm{~g}$ of $\mathrm{C}$ will be available to sustain spring vegetative growth from short distance mobilization. Since such quantities are clearly not enough to sustain this growth, we can conclude that leaf early development relies strongly on the remobilization of reserves stored during previous years (Dickson, 1989; Ferree and Palmer,1982), as reflected by a reduction of starch levels in pistachio shoots, branches and trunk (Tixier et al., 2020; Marra et al. 2017).

Reproductive growth sharply increases this early season competition for resources, reaching up to $12 \mathrm{~g}$ of $\mathrm{C}$ needed to sustain growth and respiration of leaves and fruits in highly loaded branches (4 clusters). Such a strong resource limitation during spring is likely the main cause of the lower leaf area of bearing branches with respect to non-bearing branches (Fig. 9), as previously reported for pistachio (Kamiab et al., 2020).

Early resource competition could also explain the tendency of bearing branches to have longer but thinner shoots with lower mass per unit length than non-bearing branches (Fig. 3; Table 3). This may be the result of both previous and current year branch crop load. Branches with high crop load in the current season generally have higher carbohydrate levels in early spring to support shoot growth, since during the previous year they were most likely non-bearing and able to accumulate more resources (Nzima et al., 1997a, b). However, passed the first growth flush, the non-bearing branches, that do not have to allocate resources to sustain nut growth, have more carbon readily available to support carbohydrate accumulation in the shoot and secondary growth.

The simulation performed modifying the crop load shows that in branches with lower number of clusters the AGR of the leaves in spring can be higher than the AGR of the fruits (Fig. 7), suggesting that pistachio leaf and fruit sink strength, and hence resource partitioning between them (Gifford and Evans 1981; Ho et al., 1989), may be very different based on the branch crop load.

Another important highlight from the model is the high impact that crop load has on a tree's capability to store resources later in the season. At around $100 \mathrm{DAFB}$, fruit AGR reaches a very high peak, since embryos are growing fast to fill the ovary cavity at this time. This high carbon request caused an intense reduction of photosynthetically active leaf area in bearing branches, due to early leaf drop and yellowing (Fig 4, 6 and Table 3). This is a commonly observed phenomenon in rainfed and highly crop loaded pistachio trees. Early leaf senescence has been commonly associated with a drainage of resources (namely carbohydrates and nitrogen) by the nuts (Sparks. 1977; Weinbaum 1988; Niederholzer et al., 1991; Picchioni et al., 1997; Amico Roxas et al. 2021) and it can reduce the seasonal photosynthate production of a bearing branch by $35 \%$ with respect to non-bearing neighbor branches (Marino et al 2018a).

The request for carbon to be used for fruit growth and respiration is the highest output of the budget. For example, fruit growth and respiration of four clusters with 14 fruits each would cost the branches $27 \mathrm{~g}$ of 
C, which amounts $55 \%$ of the total carbon used by the branch during the season and $78 \%$ of the carbon produced via photosynthesis. Such an intense use of carbon in highly loaded branches has been associated with flower bud drop and alternate bearing onset in pistachio (Vemmos 2010). Bud drop in our experimental conditions generally happens at around 100 DAFB (Marino et al., 2018b) - exactly when the branch carbon budget drops (Fig. 10) in response to high fruit growth rate (Fig. 7) - suggesting the strong involvement of resource competition in the bud drop event (Spann et al., 2008). Similarly, a recent study showed changes in gene expression corresponding to nutritional status, namely carbohydrates and mineral levels, in pistachio bearing branches (Benny et al., 2020).

Management strategies aiming to obtain relatively consistent yields through the years should, therefore, limit high resource drainage. This could be achieved by reducing branch sink/source ratio, increasing photosynthesis or optimizing partitioning. Pruning can influence sinksource ratio and has been very effective in reduce alternate bearing (Elloumi et al., 2014; Ferguson et al., 1995; Zhang and Ranford, 2018). Research has also shown positive effects of thinning on pistachio alternate bearing (Kamiab et al., 2020), however this practice is not adopted by growers.

Increasing photosynthetic rates at the leaf or canopy level may be challenging in well irrigated and trained orchard that are already performing maximum rates of photosynthesis and intercepting up to $80 \%$ of incoming radiation. Postponing leaf senescence may have a positive, quantifiable impact on branch seasonal cumulative carbon fixed, as derived from the model. Finally, alternate bearing can be mitigated by the use of specific rootstocks and cultivars (Kallsen et al., 2020). The bearing and growing pattern, and carbon budget of these 'less alternate bearing' genotypes should be studied and compared with more susceptible ones to develop mitigation strategies for alternate bearing in pistachio.

Further research should develop 1) physiological thresholds (such as optimal tree non-structural carbohydrates levels, branch sink-source ratio or leaf mineral status) that would prevent bud drop, and 2) comprehensive grower-friendly management protocols to achieve these thresholds in pistachio commercial orchards.

It must be pointed out that all the reported values in this study are valid for the conditions of the experiment, carried on rainfed trees grafted on $P$. therebintus rootstock. Water stress has primary effects on leaf stomatal conductance, growth and photosynthetic rates (Naor 1998; Beppu et al., 2003; Marino et al., 2018c) and may have led to an underestimation of seasonal assimilation potential of the branches. However, the model provides a solid frame that can be easily adapted to fit different growing conditions.

\section{Conclusion}

The branch carbon budget model proposed in this study is a helpful tool to better understand alternate bearing in pistachio. The model allowed to identify critical phenological phases of branch and organ development when resource competition may have the strongest impact on growth and productivity. The information developed was used to quantify the energetic cost of vegetative and reproductive growth and to identify, for the first time, the potential branch crop load that would allow a bi-annual 'carbon neutrality'.

The model can be used to test the impact of management practices on the seasonal carbon balance of pistachio branches and, ultimately, on yield and alternate bearing. For example, it could give insights about the effect of thinning, irrigation and fall defoliation on carbon dynamics and alternate bearing, or be used to describe how high temperatures associated with climate change will impact pistachio bearing patterns and nut development.

The model can be also used to shed light on the mechanisms of bearing and bud drop in pistachio. For example, it would be interesting to parametrize the model for genotypes with more and less pronounced alternate bearing to gain insight about how differently these trees produce and allocate their resources.

This information is of paramount importance to adopt physiologically-based orchard management practices that integrate plant responses to environmental changes.

\section{Author contribution}

FPM conceptualized and designed the study; GM and FPM collected and analyzed the data and developed the model. GM wrote the manuscript with substantial contribution from PGD. TC and FPM provided supervision. All authors reviewed and edited the manuscript.

\section{Declaration of Competing Interest}

The authors declare that they have no known competing financial interests or personal relationships that could have appeared to influence the work reported in this paper.

\section{Acknowledgment}

The authors wish to express their gratitude to the California Pistachio Research Board for giving continuity and funding support to this research line. The authors are grateful to Michele La Mantia for starting this research line long time ago.

\section{References}

Addicott, F.T., Lyons, J.L., 1969. Physiology of abscisic acid and related substances. Ann. Rev. Plant Physiol. 20 (3), 139-164.

Agrawal, A., Ram, S., Garg, G.K., 1980. Endogenous cytokinins of mango (Mangifera indica L.) shoot tips and significance in flowering. Indian J.Exp. Biol. 18 (5), 504-509.

Allen, M.T., Prusinkiewicz, P., DeJong, T.M., 2005. Using L-systems for modeling source-sink interactions, architecture and physiology of growing trees: the L-PEACH model. New Phytol 166 (3), 869-880.

Amico Roxas, A., Orozco, J., Guzmán-Delgado, P., Zwieniecki, M.A., 2021. Spring phenology is affected by fall non-structural carbohydrate concentration and winter sugar redistribution in three Mediterranean nut tree species. Tree Physiol. 41 (8), 1425-1438.

Amthor, J.S., 1989. Respiration and Crop Productivity. Springer, New York.

Baninasab, B., Rahemi, M., 2006. Possible role of non-structural carbohydrate in alternate bearing of pistachio. Eur. J. Hort. Sci. 71, 277-282.

Baninasab, B., Rahemi, M., 2008. Effect of exogenous polyamines on flower bud retention in pistachio (Pistacia vera L.) trees. Hortic. Environ. Biotechnol. 49, $149-154$.

Bassow, S.L., Ford, E.D., A.R., Kiester, 1990. A critique of carbon-based tree growth models. In Forest Growth: Process Modeling of Forest Growth Responses to Environmental Stress. Eds. R.K. Dixon, R.S.

Beattie, B.B., Folley, R.R.W., 1978. Production variability in apple crops. II. The long term behavior of the English crop. Sci. Hort. 8 (4), 325-332.

Benny, J., Marra, F.P., Giovino, A., Balan, B., Caruso, T., Martinelli, F., Marchese, A., 2020. Transcriptome analysis of Pistacia vera inflorescence buds in bearing and nonbearing shoots reveals the molecular mechanism causing premature flower bud abscission. Genes (Basel) 11 (8), 851.

Beppu, K., Suehara, T., Kataoka, I., 2003. High temperature and drought stress suppress the photosynthesis and carbohydrate accumulation in 'Satohnishiki' sweet cherry. Acta Hort 618, 371-377.

Bogdziewicz, M., Crone, E.E., Steele, M.A., Zwolak, R., 2017. Effects of nitrogen deposition on reproduction in a masting tree: benefits of higher seed production are trumped by negative biotic interactions. J. Ecol. 105 (2), 310-320.

Brown, P.H., Weinbaum, S.A., Picchioni, G.A., 1995. Alternate bearing influences annual nutrient consumption and the total nutrient content of mature pistachio trees. Trees 9, 158-164.

Bruchou, C., Genard, M., 1999. A space-time model of carbon translocation along a shoot bearing fruits. Ann. Bot. 84, 565-576.

Caruso, T., Fabbri, A., Giovannini, D., 1995. Inflorescence Bud Growth, Development and Abscission in Shoots of Bearing and Disbudded Bianca Pistachio Trees. J. Hortic. Sci. 70 (6), 857-866.

Chacko, E.K., Singh, N., Kachru, R.B., 1972. Study on the physiology of flowering and fruit growth in Mangiferae indica L. IV. Hormonal control of fruit development and its possible significance to biennal bearing. Acta Hort 24, 155-163.

Chacko, E.K., 1986. Physiology of vegetative and reproductive growth in mango (Mangifera indica L.) tree. In: Proceedings of 1st Australian Mango Research Workshop, Melbourne, pp. 54-70.

Chan, B.G., Chan, J.C., 1967. The effect of seed formation on subsequent flowering in apple. J. Amer. Soc. Hort. Sci. 91, 63-68. 
Chandler, W.H., 1950. Evergreen Orchards. Henry Kimpton, London.

Couranjon, J., 1989. A second cultivar factor of biennal bearing In Prunus domestica L. the sensitivity of flower bud formation to fruit load. Sci. Hort. 40 (3), 189-201.

Crane, J.C., 1984. Pistachio Production Problems. Fruit Varieties Journal 38 (3), 74-85.

Crane, J.C., Nelson, M.M., 1971. The unusual mechanism of alternate bearing in pistachio. HortScience 6 (5), 489-490.

Crane, J.C., Nelson, M.M., 1972. Effect of crop load, girdling and auxin application on alternate bearing of the pistachio. J. Amer. Soc. Hort. Sci. 97 (3), 337-339.

Crane, J.C., Al-Shalan, I.M., Carlson, R.M., 1973. Abscission of pistachio inflorescence buds as affected by leaf area and number of nuts. J. Amer. Soc. Hort. Sci. 98 (6), 591-592.

Crane, J.C., Al-Shalan, I.M., 1977. Carbohydrate and nitrogen levels in pistachio branches as related to shoot extension and yield. J. Amer. Soc. Hort. Sci. 102 (4), 396-399.

Crane, J.C., Iwakiri, B.T., 1987. Reconsideration of the Cause of Inflorescence Bud Abscission in Pistachio. Hortscience 22 (6), 1315-1316.

DeJong, T.M., 1999. Developmental and environmental control of dry-matter partitioning in peach. HortScience 34, 1037-1040.

Dickson, R.E., 1989. Carbon and nitrogen allocation in trees. Ann. Sci. For. 46, 631-647.

Elloumi, O., Ghrab, M., Mimoun, M.B, 2014. Disbudding treatments on pistachio trees cv. mateur: dry matter accumulation and distribution within fruiting and non-fruiting branches under dry climate. Trees 28 (3), 699-708.

Faust, M., 1989. Physiology of Temperate Zone Fruit Trees. Wiley, New York.

Ferguson, L., Maranto, J., Beede, R., 1995. Mechanical topping mitigates alternate bearing of Kerman' Pistachios (Pistacia vera L.). HortSci 30 (7), 1369-1372.

Ferree, D.C., Palmer, J.W., 1982. Effect of spur defoliation and ringing during bloom on fruiting, fruit mineral level and photosynthesis of "Golden Delicious" apple. J. Amer. Soc. Hort. Sci. 107, 1182-1185.

Génard, M., Lescourret, F., Mimoun, M.B., Besset, J., Bussi, C., 1998. A simulation model of growth at the shoot-bearing fruit level. II. Test and effect of source and sink factors in the case of peach. European Journal of Agronomy 9 (2-3), 189-202.

Génard, M., Dauzat, J., Franck, N., Lescourret, F., Moitrier, N., Vaast, P., Vercambre, G., 2008. Carbon allocation in fruit trees: from theory to modelling. Trees 22 (3), 269-282.

Gifford, R.M., Evans, L.T, 1981. Photosynthesis, carbon partitioning, and yield. Annua Review of Plant Physiol 32 (1), 485-509.

Goldschmidt, E.E., Monselise, S.P., 1977. Physiological assumptions towards the development of a citrus fruiting model. In: Proccedings of the International Society of Citriculture, pp. 668-672.

Grossman, Y.L., DeJong, T.M, 1994. PEACH: a simulation model of reproductive and vegetative growth in peach trees. Tree Physiol 14 (4), 329-345.

Ho, L.C., Grange, R.I., Shaw, A.F., 1989. Source/sink regulation. In: Baker, DA, Milburn, JA (Eds.), Transport and Photoassimilates, Eds. Longman Scientific and Technical, Essex, England, pp. 306-343.

Ho, L., 1988. Metabolism and compartmentation of imported sugars in sink organs in relation to sink strenght. Ann. Rev. Plant Mol. Biol. 39, 355-378.

Kallsen, C., Parfitt, D., Maranto, J., 2020. UC pistachio cultivars show improved nut quality and are ready for harvest earlier than 'Kerman. Calif Agric (Berkeley) 74 (2), 86-93.

Kamiab, F., Rasouli, P., Zamani Bahramabadi, E., 2020. Application of some bloom thinning techniques to overcome alternate bearing in pistachio (Pistacia vera $\mathrm{L}$.) Hortic. Environ. Biotechnol. 61 (1), 31-39.

Khezri, M., Heerema, R., Brar, G., Ferguson, L., 2020. Alternate Bearing in Pistachio (Pistacia Vera L.): A review. Trees, pp. 1-14.

Lacointe, A., 2000. Carbon allocation among tree organs: a review of basic processes and representation in functional-structural tree models. Ann For Sci 57, 521-533.

Lakso, A.N., Intrigliolo, D., Eissenstat, D.M., 2007. Modeling concord grapes with" VitiSim", a simplified carbon balance model: understanding pruning effects. In: VIII International Symposium on Modelling in Fruit.

Lakso, A.N., Poni, S., 2005. Vitisim"-a simplified carbon balance model of a grapevine. In: XIV International GESCO Viticulture Congress, Geisenheim, Germany, 23-27 August 2005. Groupe d'Etude des Systemes de Conduite de la vigne (GESCO), pp. 478-484.

Lakso, A.N., White, M.D., Tustin, D.S, 2000. Simulation modeling of the effects of short and long-term climatic variations on carbon balance of apple trees. In: VII International Symposium on Orchard and Plantation Systems, p. 557.

Lakso, A.N., Wunsche, J.N., Palmer, J.W., Grappadelli, L.C, 1999. Measurement and modeling of carbon balance of the apple tree. HortSci 34 (6), 1040-1047.

Lakso, A.N., Greene, D.W., Palmer, J.W., 2004. Improvements on an apple carbon balance model. In: VII International Symposium on Modelling in Fruit Research and Orchard Management, 707, pp. 57-61.

Lescourret, F., Mimoun, M.B., Génard, M., 1998. A simulation model of growth at the shoot-bearing fruit level: I. Description and parameterization for peach. European Journal of Agronomy 9 (2-3), 173-188.

Marchi, S., Guidotti, D., Sebastiani, L., Tognetti, R., 2007. Changes in assimilation capacity during leaf development in broadleaved Prunus persica and sclerophyllous Olea europaea. J. Hortic. Sci. Biotechnol. 82, 69-78.

Marino, G., La Mantia, M., Caruso, T., Marra, F.P., 2018a. Seasonal dynamics of photosynthesis and total carbon gain in bearing and nonbearing pistachio (Pistacia vera L.) shoots. Photosynthetica 56 (3), 932-941.

Marino, G., Di Martino, S., Roxas, A.A., Caruso, T., Ferguson, L., Barone, E., Marra, F.P., 2018b. Sustainability of pistachio production (Pistacia vera L.) under supplementa irrigation in a Mediterranean climate. Sci. Hort. 241, 260-266.

Marino, G., Caruso, T., Ferguson, L., Marra, F.P., 2018c. Gas exchanges and stem water potential define stress thresholds for efficient irrigation management in olive (Olea europea L.). Water (Basel) 10 (3), 342.
Marra, F.P., Barone, E., Motisi, A., Sidari, M., Caruso, T., 1997. Dry matter accumulation and carbohydrate content within branches of fruiting and deblossomed pistachio (Pistacia vera L.) trees. In: II International Symposium on Pistachios and Almonds 470, pp. 331-339.

Marra, F.P., Amico Roxas, A., Marino, G., Caruso, T., 2017. Seasonal changes in starch content in pistachio organs as related to crop load. Acta Hortic 1229, 171-176.

Marra, F.P., Barone, E., La Mantia, M., Caruso, T., 2009. Toward the definition of a carbon budget model: seasonal variation and temperature effect on respiration rate of vegetative and reproductive organs of pistachio trees (Pistacia vera). Tree Physiol 29, 1095-1103, 2009.

Marshall, B., Biscoe, P.V., 1980. A model for C3 leaves describing the dependence of net photosynthesis on irradiance. - J. Exp. Bot. 31, 29-39.

Milella, A., Agabbio, M., 1978. The position on the problem of almond growing in Sardinia. In: The Third Conference of Mediterranean Research and Study Goup on the Almond, Italy, pp. 302-310.

Monselise, S.P., Goldschmidt, E.E., Colomb, A., 1981. Alternate bearing on citrus and ways of control. In: Proceeding of the International Society of Citriculture, pp. 239-242.

Monselise, S.P., Goldschmidt, E.E., 1982. Alternate bearing in fruit trees. Hortic. Rev. 4, 128-173.

Naor, A., 1998. Relationships between leaf and stem water potentials and stomatal conductance in three field-grown woody species. J. Hortic. Sci. Biotechnol. 73, 431-436.

Niederholzer, F.J.A., Carlson, R.M., Uriu, K., Willits, N.H., Pearson, J.P., 1991. Seasonal partitioning of leaf and fruit potassium and fruit dry matter in French prune trees at various potassium levels. J. Am. Soc. Hortic. Sci. 116 (6), 981-986.

Negi, J.D.S., Manhas, R.K., Chauhan, P.S., 2003. Carbon allocation in different components of some tree species of India: a new approach for carbon estimation. Curr. Sci. 85 (11), 1528-1531.

Nzima, M.D.S., Martin, G.C., Nishijima, C., 1997a. Seasonal changes in total nonstructural carbohydrates within branches and roots of naturally "off" and "on" 'Kerman' pistachio trees. J. Am. Soc. Hortic. Sci. 122, 856-862.

Nzima, M., Martin, G., Nishijima, C., 1997b. Leaf development, dry matter accumulation, and distribution within branches of alternate bearing 'Kerman' pistachio trees. J. Amer. Soc. Hort. Sci. 122, 31-37.

Perea, R., Venturas, M., Gil, L., 2013. Empty seeds are not always bad: simultaneous effect of seed emptiness and masting on animal seed predation. PLoS ONE 8 (6), e65573.

Picchioni, G.A., Brown, P.H., Weinbaum, S.A., Muraoka, T.T., 1997. Macronutrient allocation to leaves and fruit of mature, alternate-bearing pistachio trees: magnitude and seasonal patterns at the whole-canopy level. - J. Am. Soc. Hortic. Sci. 122, 267-274.

Porlingis, I.C., 1974. Flower bud abscission in Pistachio (Pistacia vera L.) as related to fruit development and other factors. J. Amer. Soc. Hort. Sci. 99 (2), 121-125.

Post, J.J., Stam, J.C., 1983. Research on biennial bearing at the experimental garden at Werkhoven. (2) The effect of flower thinning on bud formation. Hort. Abst. 4828 (7), 469, 53.

Rosecrance, R.C., Weinbaum, S.A., Brown, P.H., 1996. Assessment of nitrogen, phosphorus, and potassium uptake capacity and root growth in mature alternatebearing pistachio (Pistacia vera) trees. Tree Physiol. 16 (11-12), 949-956.

Rosecrance, R.C., Weinbaum, S.A., Brown, P.H., 1998. Alternate bearing affects nitrogen, phosphorus, potassium and starch storage pools in mature pistachio trees. Ann. Bot. 82, 463-470.

Shibata, M., Masaki, T., Yagihashi, T., Shimada, T., Saitoh, T., 2020. Decadal changes in masting behaviour of oak trees with rising temperature. J. Ecol. 108 (3), 1088-1100.

Spann, T.M., Beede, R.H., Dejong, T.M., 2008. Seasonal carbohydrate storage and mobilization in bearing and non-bearing pistachio (Pistacia vera) trees. Tree Phys 28, 207-213.

Spann, T.M., Beede, R.H., DeJong, T.M, 2009. Contributions of short-and long-shoots to yield of 'Kerman' pistachio (Pistacia vera L.). Sci. Hort. 121 (4), 495-500.

Sparks, D., 1977. Effects of fruiting on scorch, premature defoliation, and nutrient status of 'Chickasaw' pecan leaves. - J. Am. Soc. Hortic. Sci. 102, 669-673, 1977.

Sprugel, D.G., Hinkley, T.M., Schaap, W., 1991. The theory and practice of branch autonomy. - Annu. Rev. Ecol. Syst. 22, 309-334.

Stevenson, M.T., Shackel, K.A, 1997. Alternate bearing in pistachio as a masting phenomenon: construction cost of reproduction versus vegetative growth and storage. In: II International Symposium on Pistachios and Almonds 470, pp. 340-348.

Stevenson, M.T., Shackel, K.A., Ferguson, L., 2000. Shoot length distribution and its relation to yield of alternate-bearing pistachio trees. J. Am. Soc. Hortic. Sci. 125, 165-168, 2.

Stutte, G.W., Martin, G.C., 1986. Effect of light intensity and carbohydrate reserves on flowering in olive. J. Amer. Soc. Hort. Sci. 111 (1), 27-31.

Takeda, F., Ryugo, K., Crane, J.C., 1980. Translocation and distribution of 14C-photosynthates in bearing and nonbearing pistachio branches. J. Am. Soc. Hortic. Sci. 105, 642-644.

Tixier, A., Guzmán-Delgado, P., Sperling, O., Roxas, A.A., Laca, E., Zwieniecki, M.A., 2020. Comparison of phenological traits, growth patterns, and seasonal dynamics of non-structural carbohydrate in Mediterranean tree crop species. Sci Rep 10 (1), $1-11$.

Vemmos, S.N., 1994. Net Phytosynthesis, Stomatal Conductance, Chlorophyll Content and Specific Leaf Weight of Pistachio Trees (Cv Aegenes) as Influenced by Fruiting. J. Hortic. Sci. 69 (5), 775-782.

Vemmos, S.N., 2010. Alternate bearing and the possible role of carbohydrates in bud abscission of pistachio (Pistacia vera L.). Options Méditerranéennes 94, 9-18. 
Vivin, P., Castelan, M., Gaudillere, J.P., 2002. A source/sink model to simulate seasonal allocation of carbon in grapevine. Acta Hort 584, 43-56.

Watson, M.A., Casper, B.B., 1984. Morphogenetic constraints on patterns of carbon distribution in plants. - Annu. Rev. Ecol. Syst. 15, 233-258.

- Weinbaum, S.A., 1988. Foliar nutrition of fruit trees. In: Neumann, P.M. (Ed.), Plant Growth and Leaf-Applied Chemicals, ed. CRC Press, Inc., Boca Raton, pp. 81-100.

Weinbaum, S.A., Picchioni, G.A., Muraoka, T.T., Ferguson, L., Brown, P.H., 1994. Fertilizer nitrogen and boron uptake, storage and allocation vary during the alternate-bearing cycle in pistachio trees. J. Am. Soc. Hortic. Sci. 119, 24-31.
Wetzstein, H.Y., Sparks, D., 1986. Flowering in pecans. Hortic. Rev. 8, 217-255.

Williams, M.W., 1989. Chemical thinning of apples. Hortic. Rev. 1, 270-300.

Witowski, J., 1997. Gas exchange of the lowest branches of young Scots pine: a cost benefit analysis of seasonal branch carbon budget. Tree Physiol 17, 757-765.

Zhang, J., Ranford, T., 2018. Mechanical pruning as a new approach to manage alternate bearing of 'Sirora' pistachio trees. Acta Hortic 1219, 219-228. 